\title{
Motivation to Learn Science as a Mediator between Attitude towards STEM and the Development of STEM Career Aspiration among Secondary School Students
}

\author{
Fazilah Razali", Umi Kalthom Abd Manaf, Othman Talib, Siti Aishah Hassan \\ Faculty of Educational Studies, Universiti Putra Malaysia, Serdang, 43400 Seri Kembangan, Malaysia
}

Received October 27, 2019; Revised December 2, 2019; Accepted December 24, 2019

Copyright $\bigcirc 2020$ by authors, all rights reserved. Authors agree that this article remains permanently open access under the terms of the Creative Commons Attribution License 4.0 International License

\begin{abstract}
Education system plays an important role when it is able to produce skilled labour in the Science, Technology, Engineering and Mathematics field (STEM) for industrial need. Increasing students' interest to explore science by integrating STEM in the learning process is the main agenda for the global education system to ensure the learning outcome for students to excel in the future is achieved. Therefore, the need to cultivate the attitude towards STEM and the motivation to learn science is the drive in the development of students' STEM career interest. Hence, this research will 1) Identify the direct effect of attitude towards STEM and 2) Identify the effect of mediator which is motivation to learn science towards the development of students' STEM career interest. This research is a quantitative research that uses questionnaire forms. The research respondents are comprised of 419 Form 4 science stream students in Selangor, Malaysia. The result from the study can answer the research questions by proving the influence of attitude towards STEM is significant $(p=.002)$ and the huge effect of motivation in science as mediator $(\mathrm{R} 2=.458)$ towards the development of students' STEM career interest. The result of the study is hoped to be able to give meaningful input towards students' learning as well as the importance of attitude towards STEM, and the motivation to learn science as a mediator could contribute towards detailed curriculum design and the teaching of science so that it will become more meaningful towards students' future.
\end{abstract}

Keywords Attitude towards STEM, Motivation to Learn Science, STEM Career Interest, Secondary School, Science Curriculum

\section{Introduction}

Malaysia is concerned about the education system because it wants to ensure the nation's economic development is always supported by develop of human capitals that have high level of competitive spirit. The spirit that is parallel and consistent will create revolution in the nation's education system. The revolution process includes the development of policies and goals that is adapted according to the current need of the nation's education system. Educational policy developed from Education Ordinance 1957 and currently Education Act 1996 is used as a reference for the educational system. The act highlighted not only on the development of the nation but also education as a tool to produce skilled work force in various fields including Science, Technology, Engineering and Mathematics (STEM) (Hassan, Awang, Ibrahim, \& Zakariah, 2013) [1].

Identifying students who has the potential to excel in science stream is important in order to ensure the establishment of human capitals in this nation is aligned with the nation's vision and mission. The practice of "open system" in Malaysia education system specifically in the upper secondary level has caused the enrolment of students that took subject-based art stream (such as economics, accounting, al-Quran study, commerce and courses related to languages) has surpassed students who have chosen to pursue science based subjects even though most of them are eligible to pursue science stream (Talib, Luan, Azhar, \& Abdullah, 2009) [2]. The decline in the number of students joining science stream is due to the students' perception that art stream is easier compared to science stream. It is easier for students to get good grades in art stream and this will enable students to have an easy path to go to Higher Education Institution (HEI) (Jen, Chui, \& Yong, 2013) [3]. 


\section{Literature Review}

\subsection{The Importance of Science Education}

Developed countries are always linked to the growth in science and technology. Part of the development is due to the analysis and awareness towards science curriculum development. The goal of science education is to increase mastery in science and mathematics from preschool level until higher education institution (HEI). Global development in science and technology occur rapidly; students who are less interested towards science and career in science is a global concern and it demands a reform towards science education (Liaghatdar, Soltani, \& Abedi, 2011) [4].

Malaysia Ministry of Education has decided to change Secondary School Integrated Curriculum (SSIC) and replace it with Secondary School Standard Curriculum (SSSC) in 2017 by integrating science with technology, engineering and mathematics (STEM). However, STEM approach has begun earlier through projects such as Formula 1 (F1), National Robotic Competition (NRC) and National Science Challenge (NSC) (Suhanna Zainudin, Lilia Halim, \& Zanaton Iksan, 2015) [5]. Developed nation concern towards science education development is parallel with the high demand towards skilled work force in STEM field in order to face the growing economic challenge (Kelley \& Knowles, 2016) [6].

Past researches have put much emphasis on the importance of science towards career especially towards global importance (Gottfried et al., 2016) [7], increase the nation's socio-economy (Paige, Zeegers, Llyod, \& Roetman, 2016) [8], guarantee the stabilization of technology (Onyekuru, 2015) [9] and towards a better quality development of science curriculum (Fensham, 2016) [10]. Nevertheless, in order to create students who are scientifically literate and have interest in science, various factors must be identified so that a quality skilled work force can be produced. Hence, factors that influence students' interest towards science must be evaluated in terms of students learning requirement.

\subsection{STEM Consolidation}

For more than one decade, STEM has been a national topic of discussion. The discussion was driven by the change in economic global and a demand towards more skilled work force in STEM field. The concern becomes more serious when the demand towards skilled work force increase but the awareness of the relationship between STEM career and Science education is still vague (Gottfried et al., 2016) [7]. Early planning regarding the absorption of students' knowledge towards STEM is important for students' preparation to understand clearly STEM career field. Good achievement influence students' attitude towards science and students' perception towards science will decrease through the passage of time (Bouvier, 2011)
[11]. The awareness of importance of STEM field towards students and preparation to face global challenges start by focusing on learning activities that integrate science, technology, engineering and mathematics towards an approach that could increase the students' interest towards STEM field (Micari, Van Winkle, \& Pazos, 2016) [12]. Thus, maintaining students' positive attitude towards science in secondary school level and preparing students with information regarding STEM career interest accurately is important.

\subsection{Attitude towards STEM}

Students' attitude towards STEM affects an active participation in learning session that integrates STEM element parallel with the mastery of science knowledge (Forbes \& Skamp, 2015) [13]. The growth of positive attitude towards STEM can increase students' interest in science field and profession that is related to STEM. Attitude is defined as psychological tendency by evaluating certain entities. Attitude towards STEM is different from interest towards science because attitude is more general and subjective regarding someone's relationship with environmental pressure (Uitto, 2014) [14].

Secondary school is the most active period for students to build positive attitude towards STEM and eventually leads towards various perception based on the exposure and awareness towards STEM (White \& Harrison, 2012) [15]. Therefore, secondary phase is an important period to give inspiration to students towards science and the importance of STEM career field. Low attitude towards science will influence students' motivation and later the students' interest to choose science related career. Past research shows a positive correlation between attitude and students' motivation (Narmadha \& Chamundeswari, 2013) [16]. Attitude towards STEM can be measured based on seven constructs: (1) science learning in school, (2) practical work in science, (3) science value to the community, (4) importance of science, (5) self-concept in science, (6) career choice in science field, and (7) combination of interest in science (Khisfe \& Boujaoude, 2014) [17]. Nonetheless, strong relationship between two variables which are attitude towards STEM and science motivation both affect students' interest in STEM career.

\subsection{Science Motivation}

Motivations to learn refers to the way students think about themselves by taking into consideration process and learning activity. Motivation in academic is influence by various factors including personal, social, family and culture (Togia, Korobili, \& Malliari, 2012) [18]. Motivation to learn is divided into two categories which are intrinsic motivation which is relevant to personal perception and environmental influence, while extrinsic motivation influenced by good achievement and career choice. Students will be less motivated to learn science when they 
are placed in science stream class but are not interested to learn science. Consequently, the role of parents is necessary to ensure the students maintain a positive motivation towards science (Taneja, 2016) [19]. Students who have positive motivation will show high performance in science without being influenced by environmental factors such as school categories and the teachers teaching method (Talib et al., 2009) [2].

The students nearest mediator and can influence students' motivation is parent's authority. Parents' authority level on students' motivation towards science differs according to parents' perception and academic background but research result found that there is a positive correlation between students' motivation and parents' authority towards students' interest in science (Ishak, Low, \& Lau, 2011) [20]. Parents play an important role in students' education. Therefore, identifying the level of parents' influence towards motivation is vital to increase students' interest towards science.

\section{Methodology}

Research correlation design is to measure the research's independent variable (attitude towards STEM) with independent variable (science motivation) towards dependent variable (STEM career interest). Survey method is used as research approach by using two research questionnaires Student Attitudes toward Science, Technology, Engineering, and Math and interest in STEM careers (S-STEM) and Science Motivation Questionnaire II (SMQ-II) that have been given consent to be adapted and changed according to the suitability of the research objectives which are:

1). Identifying direct effect of attitude towards STEM

2). The effect of mediator which is motivation to learn science towards the development of students' STEM career interest.

\subsection{Research Instrument}

This research utilizes an instrument to measure attitude and career, Student Attitudes toward Science, Technology, Engineering, and Math and interest in STEM careers (S-STEM). S-STEM contains 2 constructs that consists of attitude towards STEM and STEM career interest. Motivation level towards science and STEM career interest is measured by using Science Motivation Questionnaire II (SMQ-II).

\subsubsection{Student Attitudes toward Science, Technology, Engineering, and Math (S-STEM) and Interest in STEM Careers}

This questionnaire is divided into two parts; part 1 evaluates students' attitude towards STEM and part 2 evaluates students' interest in STEM career. Part 1 covers the evaluation of self-confidence towards STEM subject and $21^{\text {st }}$ century skills. The questionnaire for this part consists of 37 items and four components which are 8 items for mathematics subject, 9 items for science subject, 9 items to evaluate understanding and technology and engineering relationship in students' everyday life and 10 items to evaluate students' self-confidence in studies that involve $21^{\text {st }}$ century skills. This evaluation uses Likert scales (1-strongly disagree, 10-strongly agree). A separate section related to evaluation of students' STEM career interest; the questionnaire contains 11 items that represent profession in the science field and every profession represents work criteria that is related to science, technology, engineering or mathematic subject. This questionnaire uses Likert scales (1-Strongly uninterested, 10-Strongly interested) to measure students' interest towards career in science field.

\subsection{Location and Research Respondent}

Research location covers 10 districts in Selangor that is divided according to the two zones in Selangor. Zone 1 covers Hulu Selangor, Gombak, Petaling, Hulu Langat and Sepang districts, while Zone 2 comprises of Klang, Kuala Langat, Kuala Selangor and Sabak Bernam districts. The division of districts according to zones is based on information taken from Department of Survey and Mapping Malaysia (2017) [21]. The school chosen is secondary school and 419 form 4 students from the science stream are chosen as research respondents. Proportionate Stratified Random Sampling is used as sampling method.

\subsection{Pilot Study}

Pilot study is carried out to test whether the instruments that are being used can be measured well. Alpha Cronbach is used to measure the reliability of the research instruments (Zainudin Awang, 2010; 2012) [22]. The pilot study is executed to measure each research items so that they can be well understand by the respondents and there is no confusion in terms of language and meaning that could affect the result of the research later (Sekaran, 2013) [23]. The pilot study is carried out on 100 respondents that comprise of secondary form 4 science stream students. Based on the result of the data analysis of the study, it is found that the alpha Cronbach value is more than .70 (Table 1) and all items for both instruments are accepted (Hair, Black, Babin, \& Anderson, 2010) [24]. Therefore, both instruments can be used for field research. 
Table 1. Instruments Reliability

\begin{tabular}{ccc}
\hline Instrumen & Construct & Alpha Cronbach \\
\hline Student Attitudes toward Science, Technology, Engineering, \\
$\begin{array}{c}\text { and Math } \\
\text { (S-STEM) and Interest in STEM Career }\end{array}$ & Atitude Towards STEM & 0.838 \\
\hline Science Motivation Questionnaire II (SMQ-II) & Interest STEM Career & 0.863 \\
\hline
\end{tabular}

\section{Results}

\subsection{Confirmatory Factor Analysis (CFA)}

CFA was performed to evaluate unidimensionality, validity and reliability of measurement model that consists of latent construct (unmeasurable) (Cresswell, 2012) [25]. Measurement model is an analysis that is carried out on constructs that is summarized in the form of line chart (Hair et al., 2010) [24]. The purpose of CFA was to evaluate models based on theory. CFA focused on items that were consistent and dominant to evaluate every research construct. According to Hair et al., (2010) [24] model has fit index according to set categories and it must be achieved to validate that the measurement model meets the suitable index as seen in Table 2:

Table 2. Model fit indexes according to Hair et al. Indexes (2010)

\begin{tabular}{ccc}
\hline Categories & Index Name & Accepted Index Value \\
\hline \multirow{3}{*}{ Absolute Fit } & Chisq & $>0.05$ \\
\cline { 2 - 3 } & RMSEA & $<0.08$ \\
\cline { 2 - 3 } & GFI & $>0.90$ \\
\cline { 2 - 3 } Incremental Fit & AGFI & $>0.90$ \\
\cline { 2 - 3 } & CFI & $>0.90$ \\
\cline { 2 - 3 } & TLI & $>0.90$ \\
\hline Parsimonious Fit & NFI & $>0.90$ \\
\hline
\end{tabular}

Based on the analysis result, it was found that the measurement model passed the majority fit index value that involved all three categories which were Chisq, RMSEA, CFI, TLI, Chisq/df and the value of $\mathrm{p}$ (Figure 1). As stated by Schreiber et al. (2006) [26] measurement model that fulfill majority of the model fit indexes value shows that it is a good and accepted measurement model.

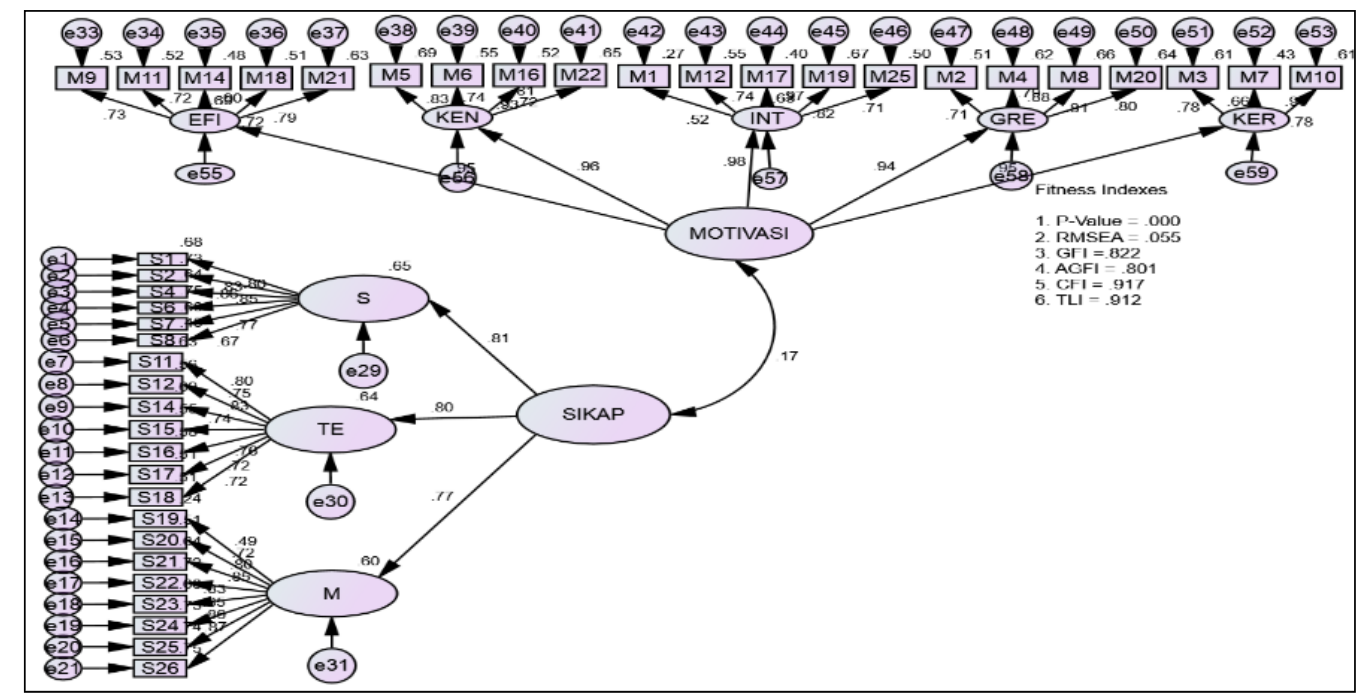

*Attitude (SIKAP) and Motivation (Motivasi)

Figure 1. Measurement Model between Attitude towards STEM and Science Motivation

The findings from the measurement model had also achieved indexes at least one index for every category (Table 3). Measurement model that achieved at least one index for every category is a model that achieved suitability index model 
and is accepted for next analysis (Hair et al., 2010) [24]. Hence, this research took the bolded index value to represent each category.

Table 3. Model Fit Indexes for Measurement Model

\begin{tabular}{cccc}
\hline Categories & Index Name & Accepted Index Value & Measurement Model \\
\hline \multirow{3}{*}{ Absolute Fit } & Chisq & $>0.05$ & 1763.629 \\
\cline { 2 - 4 } & RMSEA & $<0.08$ & .055 \\
\cline { 2 - 4 } & GFI & $>0.90$ & .822 \\
\hline \multirow{3}{*}{ Incremental Fit } & AGFI & $>0.90$ & .801 \\
\cline { 2 - 4 } & CFI & $>0.90$ & .917 \\
\cline { 2 - 4 } & TLI & $>0.90$ & .912 \\
\cline { 2 - 4 } & NFI & $>0.90$ & .879 \\
\hline Parsimonious Fit & Chisq/df & $<5.0$ & 2.180 \\
\hline
\end{tabular}

\subsection{Structure Model}

Analysis result of the measurement model had fulfilled the requirement for model fit indexes. Therefore, the next analysis will be conducted to evaluate models in order to answer the research objectives which are:

1. Identifying direct result of attitude towards STEM

2. The effect of mediator which is motivation to learn science towards the development of students' STEM career interest.

\subsubsection{Direct Effect}

Direct effect is the effect of influence that occurs between exogenous variable and endogenous variable. Identifying direct effect is also part of an important foundation before performing analysis towards the effect of mediator. Independent variable that directly does not have a significant value towards dependent variable will cause the result of the research to be not accurate in determining the mediator (Aguinis, Edwards, \& Bradley, 2016) [27]. Thus, the research had performed direct analysis that involves both the independent variables which were attitude towards STEM and science motivation towards the development of STEM career interest. of mediator value for value of $\mathrm{p}$ which was less than .05 and becomes the foundation value to measure the value of $\mathrm{p}$ for social science field (Aytekin, Erdil, Erdogmus, \& Akgun, 2016) [28]. Furthermore, attitude towards STEM also achieved the requirement for next analysis which is the determination. Significant influence $(\beta=.201, \mathrm{p}=.002)$ (Table 4) based on the structure model built. The research also used significant and development of STEM career interest (KERSTEM) had Direct influence between attitudes towards STEM (SIKAP).

(i) Direct Effect of Attitude towards STEM and Development of STEM Career Interest

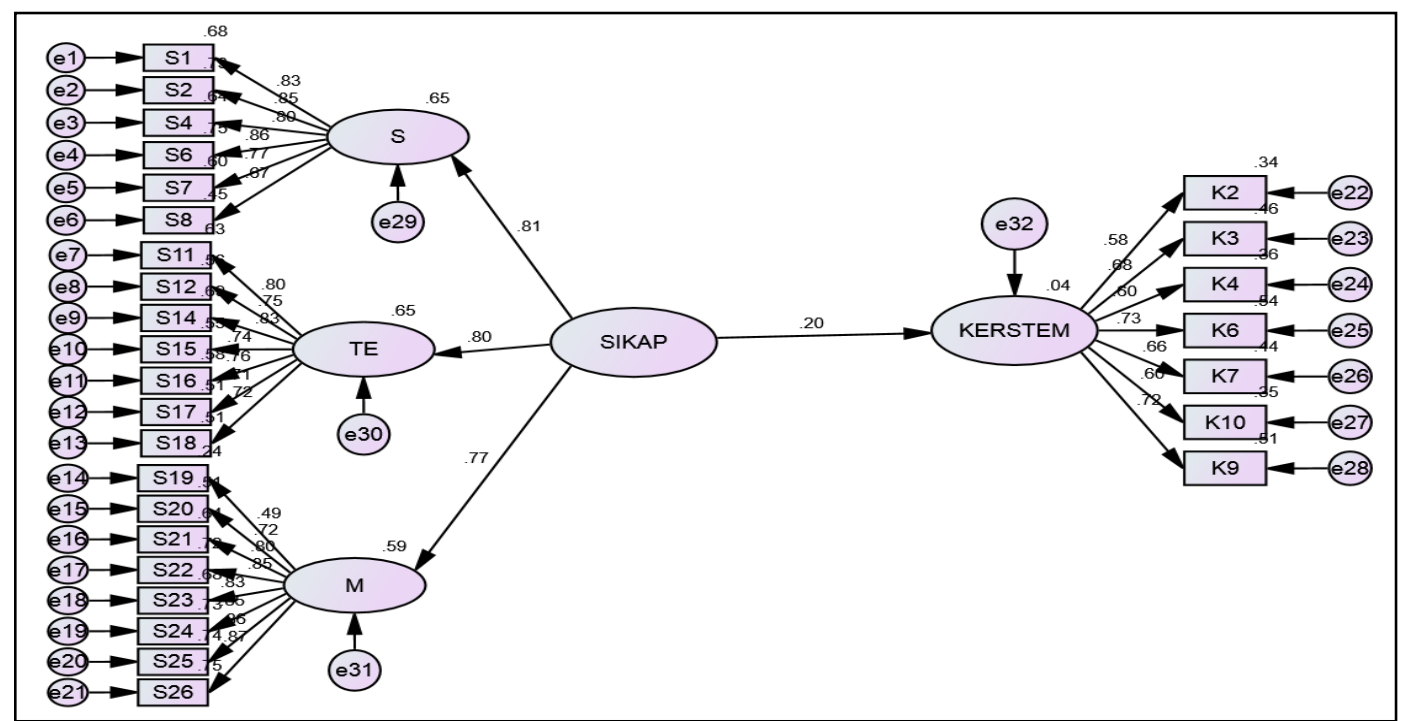

*Attitude (SIKAP) and STEM Career (KERSTEM)

Figure 2. Direct Influence of Attitude towards STEM and Development of STEM Career Interest Model

Figure 2 shows direct influence of attitude towards STEM and development of students' STEM career interest model. 


\subsubsection{Direct Effect of Science Motivation and Development of STEM Career Interest}

Table 4. Evaluation of Direct Effect of Attitude towards STEM and Development of STEM Career Interest

\begin{tabular}{cccccc}
\hline & Construct & & Estimate & $\begin{array}{c}\text { Standard } \\
\text { Estimate }\end{array}$ & P \\
\hline $\begin{array}{r}\text { STEM } \\
\text { Career }\end{array}$ & $<---$ & Attitude & .201 & .247 & .002 \\
\hline
\end{tabular}

Figure 3 shows direct model between science motivation and development of STEM career interest. Result showed that science motivation (MOTIVASI) statistically had significant value towards the development of STEM career interest (KERSTEM) $(\beta=.598, \mathrm{p}<.001)$ (Table 5). Thus, research to determine the mediator can be carried out for science motivation variable because it has a direct effect that is significant.

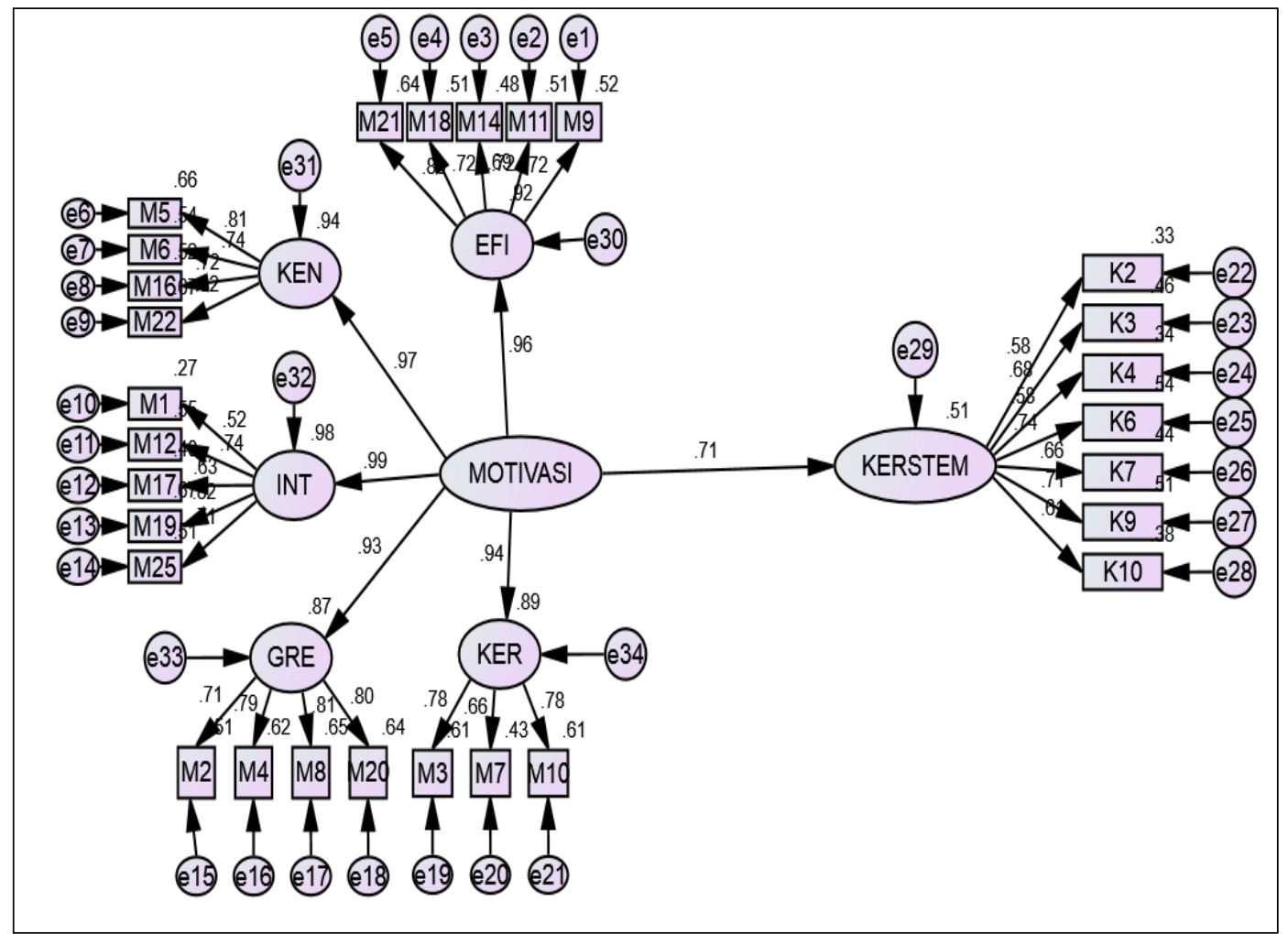

* Motivation (Motivasi) and STEM Career (KERSTEM)

Figure 3. Direct Effect of Science Motivation and Development of STEM Career Interest Model

Table 5. Evaluation of Influence of Science Motivation and Development of STEM Career Interest

\begin{tabular}{lccccc}
\hline & \multicolumn{2}{c}{ Construct } & Estimate & Standard Estimate & P \\
\hline STEM Career & $<---$ & Motivation & .598 & .713 & $* * *$
\end{tabular}

\subsubsection{Science Motivation as Mediator}

This section will discuss on the role of science motivation as mediator between influence of attitude towards STEM and parents' authority in developing students' STEM career interest according to the modification model. Therefore, analysis was executed to determine whether mediator exists between independent variable and dependent variable which is categorized as full mediation, partial mediation and non-mediation. 


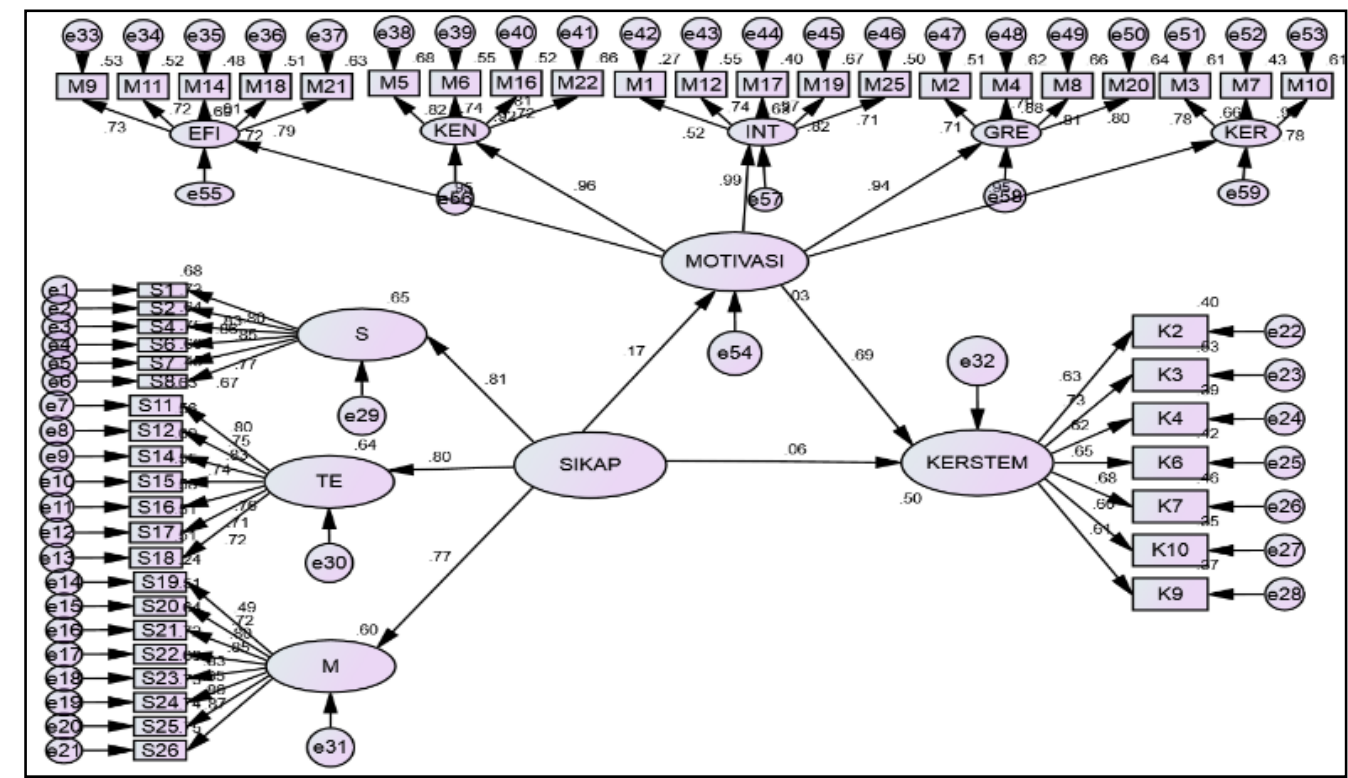

* Motivation (MOTIVASI), Attitude (SIKAP) and STEM Career (KERSTEM)

Figure 4. Motivation as a Mediator between Attitude towards STEM and Development of STEM Career Interest

When mediator was evaluated in the proposed model (Figure 4), the beta coefficient value (estimate) reduced from .598 (refer Table 5) to .080 (refer Table 6). The reduction in value refers to a decrease in direct influence and had switched towards mediator and brought in an insignificant value of $p$ at value of $p<0.05$ between attitude towards STEM and students' STEM career interest. In short, the influence of mediator (indirect influence) for Attitude $\rightarrow$ Motivation, $(\beta=.181, \mathrm{p}=.002)$ and Motivation $\rightarrow$ STEM Career, $(\beta=.568, \mathrm{p}<.001)$ were significant.

Table 6. Regression Weight between Attitude towards STEM and Development of STEM Career Interest

\begin{tabular}{cccccc}
\hline & & & Estimate & $\begin{array}{c}\text { Standard } \\
\text { Estimate }\end{array}$ & P \\
\hline STEM Career & $<--$ & Attitude & .080 & .145 & .221 \\
\hline STEM Career & $<---$ & Motivation & .664 & .568 & $* * *$ \\
\hline Motivation & $<---$ & Attitude & .249 & .181 & .002 \\
\hline
\end{tabular}

The type of mediator that exists between attitude towards STEM and STEM career interest was Full Mediation for the value of $\mathrm{p}$ less than 0.05 . Full Mediation showed that direct effect between independent variable (IV) and dependent variable (DV) was insignificant when mediator exist within model.

\subsubsection{Description of Coefficient of Determination $\left(\mathrm{R}^{2}\right)$ Model}

Coefficient of determination between the influence of exogenous and endogenous variables, squared multiple correlation $\left(\mathrm{R}^{2}\right)$ must be taken into consideration to determine the overall research contribution based on the modification model that was produced suitable with the chosen independent variables. Determination of $\mathrm{R}^{2}$ for a complete model is vital to determine the overall effect of the involved exogenous towards endogenous in the research through the usage of SEM (Hair et al., 2010) [24]. In brief, determining $\mathrm{R}^{2}$ value in the research is vital to measure the overall effect of independent variables which are attitude towards STEM, parents' authority and science motivation towards development of students' STEM career interest accurately based on the complete model.

Table 7. Determination $\left(\mathrm{R}^{2}\right)$ Structure Model

\begin{tabular}{lc}
\hline & Estimate \\
\hline STEM Career & .499 \\
\hline
\end{tabular}

According to Table 7, overall effect or contribution of variables influence in research model to predict the development of students' STEM career interest recorded a variance value of .499 or 49.9\%. Kline (2011) [29] stated that variance value that is more than .30 and above (refer Table 8 ) contributes a huge effect in influencing the overall research result. Hence, the effect of influence of attitude towards STEM and science motivation towards development of STEM career interest was strong among Form Four science students. 
Table 8. The Value of $\mathrm{R}^{2}$ and Research Effect Size

\begin{tabular}{cc}
\hline $\mathbf{R}^{2}$ & Effect Size \\
\hline$<.01$ & Small \\
\hline $\mathbf{. 1 0}-. \mathbf{2 9}$ & Medium \\
\hline$>. \mathbf{3 0}$ & Large \\
\hline
\end{tabular}

\section{Discussion}

The effect of indirect influence (mediator) exists between independent variables for attitude towards STEM to development of STEM career interest with science motivation as mediator. Result of analysis found that science motivation as mediator between attitude towards STEM towards development of STEM career interest recorded a high value of variance which was .499 or $49.9 \%$ and it brought effect or huge contribution of influence towards students' STEM career interest. Besides, the result of mediator determination found the effect of full mediation for science motivation as mediator between attitude towards STEM and development of STEM career interest. In conclusion, showing students' need especially for adaptation process from overflow of STEM information is substantial to provide preparation for students to adapt the need and importance of STEM for future industrial revolution.

\section{Conclusion}

Proposed model of influence of attitude towards STEM and science motivation is one of the ways to identify students' interest tendency towards STEM career specifically through statistic evaluation. Moreover, researcher evaluates the extent of the consistency of students from the science stream that achieved good grades in science and mathematics subject to be interested in STEM career.

The research also gives positive impact on science education towards the production of students that are able to compete in STEM's industry by providing significant contribution based on the research result that had been carried out. This is said as such because the research had combined accurate variables to translate information from Secondary School Standard Curriculum (SSSC) to channel the importance of STEM to students more comprehensively especially to students in the secondary school level and school community. Attitude towards STEM and science motivation model had gone through a systematic validation process and had been evaluated with testing of direct and indirect influence towards each of the involved variables.

\section{Recommendation for Practice and}

\section{Future Studies}

The study that was performed was based on specific objectives developed at the beginning of the study to be carried out for specific scope. Thus, there was limitation in the execution of the study. This section will discuss on research limitation and will suggest a few steps that must be taken for future research in order to ensure a better discovery can be contributed especially in curriculum development.

The research that was carried out was a full quantitative method research. Data was collected through findings from respondents; among students who answered the questionnaires. However, the research did not involve data collection through interviews, building lesson modules, experimenting or methods that are deemed suitable to identify influence towards students' STEM career interest. Further study that involves teachers as research respondents can also provide views from different perspective as an effort to develop students' career interest based on approach such as lesson plan, activity conducted, and teachers' readiness to implement STEM in their teaching. In conclusion, the need to diversify research method and respondents to gain better influence factor will provide different essence towards development of STEM career interest among students.

\section{REFERENCES}

[1] Hassan, Razali and Awang, Halizah and Ibrahim, Badaruddin and Zakariah, Siti Hajar (2013) Memacu pelan transformasi pendidikan: peranan IPTA dalam membantu meningkatkan kuantiti dan kualiti Pendidikan Aliran Sains dan Teknikal di Malaysia. In: Seminar Kebangsaan Kali ke-4 Majlis Dekan Pendidikan IPTA 2013, 23-25 September 2013, Universiti Islam Antarabangsa Malaysia

[2] Othman Talib, Luan, W. S., Azhar, S. C., \& Abdullah, N. (2009). Uncovering Malaysian students' motivation to learning science. European Journal of Social Sciences, 8(2), 266-276.

[3] Jen, S., Chui, B., \& Yong, S. (2013). Secondary School Students' Motivation and Achievement in Combined Science. US-China Education Review B, 3(4), 213-228.

[4] Liaghatdar, M. J., Soltani, A., \& Abedi, A. (2011). A Validity Study of Attitudes toward Science Scale among Iranian Secondary School Students. International Education Studies, 4(4), 36-47. http://doi.org/10.5539/ies.v4n4p36.

[5] Suhanna Zainudin, Lilia Halim, \& Zanaton Iksan. (2015). How $60: 40$ Policy Affects The Development Of Science Curriculum In Malaysia. In Volume 3 Proceeding: 7th International Seminar on Regional Education, November 5-7, 2015 (Vol. 3, pp. 1396-1405).

[6] Kelley, \& Knowles, J. G. (2016). A conceptual framework for integrated STEM education. International Journal of STEM Education, $3(1), \quad 11$. 
http://doi.org/10.1186/s40594-016-0046-z

[7] Gottfried, A. E., Preston, K. S. J., Gottfried, A. W., Oliver, P. H., Delany, D. E., \& Ibrahim, S. M. (2016). Pathways from parental stimulation of children's curiosity to high school science course accomplishments and science career interest and skill. International Journal of Science Education, $38(12)$, http://doi.org/10.1080/09500693.2016.1220690 1972-1995.

[8] Paige, K., Zeegers, Y., Lloyd, D., \& Roetman, P. (2016). Researching the Effectiveness of a Science Professional Learning Programme Using a Proposed Curriculum Framework for Schools: A Case Study. International Journal of Science and Mathematics Education, 14(1), 149 175. http://doi.org/10.1007/s10763-014-9569-2

[9] Onyekuru, B. U. (2015). Field Dependence-Field Independence Cognitive Style, Gender, Career Choice and Academic Achievement of Secondary School Students in Emohua Local Government Area of Rivers State. Journal of Education and Practice, 6(10), 76-86.

[10] Fensham, P. J. (2016). The Future Curriculum for School Science: What Can Be Learnt from the Past? Research in Science Education, 20(4). http://doi.org/10.1007/s11165-015-9511-9

[11] Bouvier, S. (2011). Increasing Student Interest in Science, Technology, Engineering, and Math (STEM): Massachusetts STEM Pipeline Fund Programs Using Promising Practices. Report Prepared for the Massachusetts Department of Higher Education. UMass Donahue Institute Research and Evaluation Group i.

[12] Micari, M., Van Winkle, Z., \& Pazos, P. (2016). Among friends: the role of academic-preparedness diversity in individual performance within a small-group STEM learning environment. International Journal of Science Education, 38(12), 1904-1922.

http://doi.org/10.1080/09500693.2016.1218091

[13] Forbes, A., \& Skamp, K. (2015). Secondary Science Teachers and Students Involvement in a Primary School Community of Science Practice: How It Changed Their Practices and Interest in Science. Research in Science Education, 91-112. http://doi.org/10.1007/s11165-014-9457-3

[14] Uitto, A. (2014). Interest, attitudes and self-efficacy beliefs explaining upper-secondary school students' orientation towards biology-related careers. International Journal of Science and Mathematics Education, 12(6), 1425-1444. http://doi.org/10.1007/s10763-014-9516-2

[15] White, \& Harrison, T. G. (2012). Uk School Students' Attitudes Towards Science and Potential Science - Based C Areers. Acta Didactica Napocensia, 5(4), 1-10.

[16] Narmadha, \& Chamundeswari. (2013). Attitude towards Learning of Science and Academic Achievement in Science among Students at the Secondary Level. Journal of Sociological Research, 4(2), 114-124. http://doi.org/10.5296/jsr.v4i2.3909

[17] Khishfe, R., \& Boujaoude, S. (2014). Lebanese Students' Conceptions of and Attitudes. International Journal of Science and Mathematics Education, 14(1), 145-167.

[18] Togia, A., Korobili, S., \& Malliari, A. (2012). Motivation to learn and learning strategies: IT courses in a library and information science department. International Journal of Sustainability in Higher Education, 61(November), 41-56. http://doi.org/10.1108/00242531211207415

[19] Taneja, A. (2016). Argumentation in Science Class: Its Planning, Practice, and Effect on Student Motivation, $\mathrm{PhD}$ Thesis, Walden University.

[20] Ishak, Z., Low, S. F., \& Lau, P. L. (2011). Parenting Style as a Moderator for Students' Academic Achievement. Journal of Science Education and Technology, 21(4), 487-493. http://doi.org/10.1007/s10956-011-9340-1

[21] Department of Survey and Mapping Malaysia. Retrieved 21 August 2017 from https://www.jupem.gov.my/v1/my/info-jupem/jupem-nege ri/jabatan-ukur-dan-pemetaan-selangor/

[22] Zainudin Awang. (2015). Structural Equation Modeling Using AMOS. MPWS Rich Publication.

[23] Sekaran, U. (2013). Research Methods for Business A Skill Building Approach. (J. C. Marshall, Ed.), Research methods for business (Fourth, Vol. 65). John Wiley \& Sons, Inc. http://doi.org/10.1017/CBO9781107415324.004

[24] Hair, J., Black, W. C., Babin, B. J., \& Anderson, R. E. (2010). multivariate data analysis (7th ed.). Pearson Prentice Hall.

[25] Creswell, J. W. (2012). Educational research: Planning, conducting, and evaluating quantitative and qualitative research. Educational Research (Vol. 4). http://doi.org/10.1017/CBO9781107415324.004

[26] Schreiber, J. B., Nora, A., Stage, F. K., Barlow, E. A., \& King, J. (2006). Modeling and Confirmatory Factor Analysis Results: A Review. The Journal of Education Reasearch, 99(6), 323-338.

[27] Aguinis, H., Edwards, J. R., \& Bradley, K. J. (2017). Improving Our Understanding of Moderation and Mediation in Strategic Management Research. Organizational Research Methods, 20(4), 665-685. http://doi.org/10.1177/1094428115627498

[28] Aytekin, I., Erdil, O., Erdoğmuş, N., \& Akgün, A. E. (2016). Academicians' career capital and career satisfaction: The mediation effect of research productivity. Educational Sciences: Theory \& Practice, 16, 1921-1945

[29] Kline, R. B. (2011). Principles and practice of structural equation modeling. New York: Guillford Press. (Vol. 156). http://doi.org/10.1038/156278a0 